W. Goebel, S. Kathariou, M. Kuhn, Z. Sokolovic, J. Kreft, S. Köhler, D. Funke, T. Chakraborty, M. Leimeister-Wächter

\title{
Hemolysin from Listeria - Biochemistry, Genetics and Function in Pathogenesis
}

Summary: Thiol-activated hemolysins (listeriolysins) from Listeria monocytogenes (Sv4b) and Listeria ivanovii were purified to homogeneity. The $\mathrm{N}$-terminal amino acid sequences of the $58 \mathrm{kDa}$ listeriolysin of $L$. ivanovii and of a $24 \mathrm{kDa}$ protein which may represent the CAMP-factor of $L$. ivanovii were determined. Antibodies raised against the $L$. ivanovii listeriolysin and anti-streptolysin $\mathrm{O}$ antibodies were used in Western blot analyses to detect listeriolysin(s) in virulent and avirulent Listeria strains. It was found that all virulent strains of $L$. monocytogenes synthesize and secrete listeriolysin ( $\mathrm{Mr}$ 58-59 $\mathrm{kDa}$ ), albeit in significantly variable quantities. No protein cross-reaction with anti-listeriolysin antibodies or anti-streptolysin $\mathrm{O}$-antibodies was present in the supernatant of Listeria innocua, Listeria welshimeri, Listeria grayi and Listeria murrayi strains. Furthermore, the avirulent but hemolytic Listeria seeligeri did not cross-react with these antibodies. In a L. monocytogenes (strain EGD) gene bank constructed in Escherichia coli two types of hemolytic clones were identified. The first type carried recombinant plasmids with a common $2.0 \mathrm{~kb}$ fragment coding for a $23 \mathrm{kDa}$ protein. This hemolytic activity was not activated by DTT and the $23 \mathrm{kDa}$ protein did not cross react with anti-listeriolysin or anti-

Zusammenfassung: Hämolysin von Listerien - Biochemie, Genetik und Funktion in der Pathogenese. SH-aktivierbare Hämolysine (Cytolysine) aus Listeria monocytogenes (Sv4b) und Listeria ivanovii wurden zur Homogenität gereinigt. Die $\mathrm{N}$-terminalen Aminosäuresequenzen des $58 \mathrm{kDa}$ großen Listeriolysins aus $L$. ivanovii und eines $24 \mathrm{kDa}$ Protein, das vermutlich der CAMP-Faktor von $L$. ivanovii ist, wurden bestimmt. Mit Hilfe von Antikörpern gegen Listeriolysin aus L. ivanovii und Streptolysin O wurden im Western Blot virulente und avirulente Listerienstämme auf ihre Fähigkeit, Listeriolysin zu bilden, getestet. Danach synthetisieren und scheiden alle virulenten Stämme von $L$. monocytogenes $\mathrm{Li}$ steriolysin ( $\mathrm{Mr}$.58-59 $\mathrm{kDa}$ ) aus, allerdings in sehr unterschiedlicher Menge. In den Kulturüberständen von Listeria innocua, Listeria welshimeri, Listeria grayi und Listeria murrayi konnte kein mit Listeriolysin- oder Streptolysin-O-Antikörpern kreuzreagierendes Protein nachgewiesen werden. Die avirulente, aber hämolytische Art Listeria seeligeri zeigte ebenfalls keine Kreuzreaktion mit diesen Antikörpern. Zwei Typen von hämolytischen Escherichia coli Klonen wurden in einer Genbank von L. monocytogenes (Stamm EGD) nachgewiesen. Der erste Typ besa $B$ rekombinante Plasmide, die ein gemeinsames Fragment von 2 kb trugen. Dieses kodierte für ein Protein von $23 \mathrm{kDa}$, das für die hämolytische Aktivität verantwortlich ist. Diese Aktivität wurde weder mit DTT aktiviert, noch kreuzreagierte das 23-kDa-Protein

\section{Introduction}

Most clinical isolates of Listeria belong to the species $L i s$ teria monocytogenes. All of these strains are also virulent in an experimental murine model $(1,2)$. A reduced viru- streptolysin antibodies. The other type of hemolytic clones was detected by using anti-streptolysin $O$ antibodies to screen the gene bank. Some of these clones synthesized a protein of $61 \mathrm{kDa}$ which cross reacted with anti-streptolysin O (or anti-listeriolysin) antibodies. By transposon Tn916 mutagenesis of $L$. monocytogenes two types of nonhemolytic mutants were obtained. Type I produced no extracellular protein that cross reacted with anti-listeriolysin (or anti SLO) antibodies. Instead of the $58 \mathrm{kDa}$ listeriolysin protein, type II mutants released proteins which were smaller in size than listeriolysin and cross reacted with anti-SLO. These proteins probably represent truncated listeriolysins. Virulence tests in a mouse model indicated that non-hemolytic mutants of $L$. monocytogenes were avirulent. Furthermore, it was shown that these nonhemolytic mutants were unable to survive in mouse peritoneal macrophages but were still capable of entering mouse embryo fibroblast (3T6) cells. All virulent $L$. monocytogenes produced a quantitatively abundant extracellular protein of $\mathrm{Mr} 60 \mathrm{kDa}$. We isolated mutants which were still hemolytic but produced significantly reduced amounts of this protein. The ability of these mutants to enter 3T6 cells was severely impaired.

mit Antikörpern gegen Listeriolysin oder Streptolysin O. Der andere Typ von hämolytischen Klonen wurde in der Genbank mit Hilfe von Streptolysin-O-Antikörpern identifiziert. Einige dieser Klone synthetisierten ein Protein von 61 kDa, das mit Antikörpern gegen Streptolysin O (oder Listeriolysin) kreuzreagierte. Durch Transposonmutagenese von L. monocytogenes mit Tn916 wurden 2 Typen von nichthämolytischen Mutanten erhalten. Mutanten des Typs I produzierten kein extrazelluläres Protein, das mit Antikörpern gegen Listeriolysin kreuzreagierte. Typ-II-Mutanten schieden anstelle des $58 \mathrm{kDa}$ Listeriolysins Proteine mit geringerer Größe als Listeriolysin aus, die noch mit diesen Antikörpern reagierten und somit wahrscheinlich verkürzte Listeriolysinproteine darstellen. Tests auf Virulenz in einem Mausmodell zeigten, daß beide Typen von nichthämolytischen Mutanten avirulent sind. Weiterhin konnte gezeigt werden, daB diese nichthämolytischen Mutanten nicht mehr in der Lage sind, in peritonealen Mausmakrophagen zu überleben, jedoch noch in embryonale Mäusefibroblasten (3T6-Zellen) eindringen können. Alle virulenten Stämme von $L$. monocytogenes synthetisierten in relativ großer Menge ein extrazelluläres Protein von $60 \mathrm{kDa}$. Mutanten konnten isoliert werden, die zwar noch hämolytisch sind, das $60-\mathrm{kDa}$-Protein jedoch nur noch in geringer Menge produzieren. Die Mutanten haben die Fähigkeit, in 3T6-Zellen einzudringen, weitgehend verloren.

Prof. Dr. W. Goebel, Dr. S. Kathariou, Dipl. Biol. M. Kuhn, Z. Sokolovic, Priv.-Doz. Dr. J. Kreft, Dipl. Biol. S. Köhler, Dipl. Biol. D. Funke, Dr. T. Chakraborty, Dipl.-Biol. M. Leimeister-Wächter, Institut für Genetik und Mikrobiologie, Universität Würzburg; Röntgenring 11, D-8700 Würzburg. 
lence was demonstrated in this animal model for Listeria ivanovii (3). All known virulent strains produce hemolysin whereas non-hemolytic Listeria strains are avirulent. The hemolysin, termed listeriolysin, has therefore been implicated as an important virulence factor in infections caused by $L$. monocytogenes. Studies using non-hemolytic transposon mutants of $L$. monocytogenes support this assumption $(4,5)$. The existence of the avirulent, but hemolytic Listeria species, Listeria seeligeri, has raised the question whether only one "listeriolysin" may exist in Listeria, and recently, the presence of more than one hemolysin in clinical isolates has been postulated (6). The only hemolysin characterized biochemically is the thiolactivated listeriolysin which is a member of a group of cytolysins produced by several gram-positive bacteria. These cytolysins cross react immunologically and recognize cholesterol as common receptor $(7,8)$. The well studied streptolysin O (SLO) belongs to this group and it has previously been demonstrated that antibodies raised against SLO cross react with the SH-activated listeriolysin (6).

\section{Results and Discussion}

Purification and Characterization of SH-activated Hemolysins (listeriolysins) from Listeria ivanovii and Listeria monocytogenes $S v 4 b$

Listeriolysin from Listeria ivanovii (ATCC 19119, SLCC 2379) and L. monocytogenes Sv4b (NCTC 10527) was purified essentially as described by Geoffroy and Alouf (9). SH-reactive proteins from the culture supernatants were separated from other extracellular proteins by chromatography on thiopropyl-Sepharose 6B (in PBS pH 6.0) from which they were eluted with $5 \mathrm{mM}$ 1.4-dithioerythritol (DTT) in PBS pH 7.5. Active fractions were purified by gel filtration on Biogel P-100 and subsequently on FPLC-Superose 6 . Figure 1 shows the protein pattern obtained by SDS-PAGE after the two initial purification steps. In the case of $L$. monocytogenes $\mathrm{Sv} 4 \mathrm{~b}$ a single protein with $\mathrm{MW}$ of $58 \mathrm{kDa}$ was obtained, whereas in the case of $L$. ivanovii two proteins of $\mathrm{MW} 58 \mathrm{kDa}$ and 24 $\mathrm{kDa}$ were copurified. Interestingly, the latter proteins seemed to form a rather stable complex and could not be separated from each other under non-denaturing conditions, i. e. by gel filtration on Biogel-P-100 or on FPLCSuperose 6 (data not shown). Only after addition of $0.1 \%$ SDS was separation of the two components achieved on FPLC-Superose 6 (data not shown).

The purified hemolysin preparations from $L$. ivanovii and $L$. monocytogenes Sv $4 \mathrm{~b}$, respectively, showed all the characteristics typical for listeriolysin $(7,8)$, i. e. activation by SH-reagents and inhibition by cholesterol (data not shown). The isolated $24 \mathrm{kDa}$ protein from $L$. ivano$v i i$, which itself showed a slight, non-DTT-dependent hemolytic activity, exhibited a strong dose-dependent hemolytic effect on sheep erythrocytes when combined with a culture supernatant from Rhodococcus equi. No such reaction was observed with a supernatant from Staphylococcus aureus (Figure 2). This. behaviour is typical for the CAMP-phenomenon observed with $L$. ivanovii and $R$. equi (10). The $\mathrm{N}$-terminal amino acid sequences of both the $58 \mathrm{kDa}$ listeriolysin and the $24 \mathrm{kDa}$ protein from L. ivanovii were determined by microsequencing in a gas phase protein sequenator (Figure 3). The amino acid sequence of the $58 \mathrm{kDa}$ protein shows no homology to the $\mathrm{N}$-termini of other SH-activated cytolysins (11). The comparison of the two sequences also demonstrates that the $24 \mathrm{kDa}$ protein is not an N-terminal fragment of $58 \mathrm{kDa}$ protein. The determination of the amino acid sequence of the $58 \mathrm{kDa}$ listeriolysin from $L$. monocytogenes Sv $4 \mathrm{~b}$ and a further characterization of the $24 \mathrm{kDa}$ protein from $L$. ivanovii are in progress. Rabbit antiserum raised against

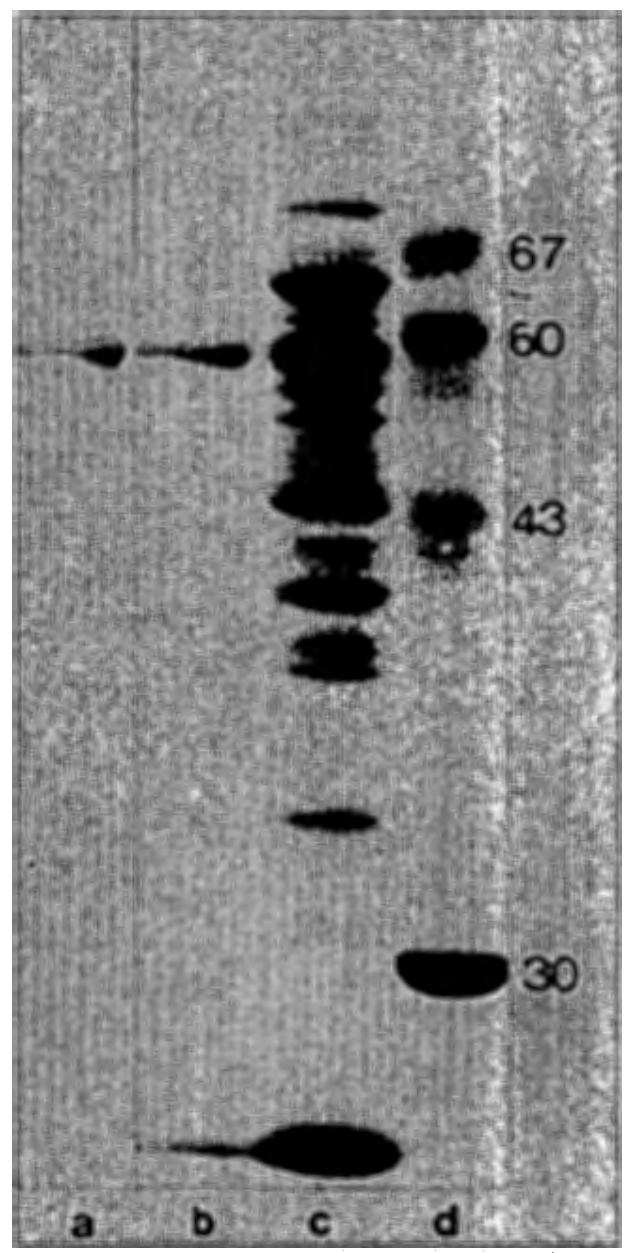

Figure 1: Analysis of the purified hemolysin from Listeria monocytogenes (Sv4b) (a) and Listeria ivanovii; (b) on SDSPAGE after chromatography of concentrated culture supernatants on thiopropyl-Sepharose 6B and on Biogel P-100; (c) shows the protein pattern of the crude concentrated supernatant of Listeria ivanovii before purification; (d) marker proteins with the indicated relative molecular masses in kDa. 


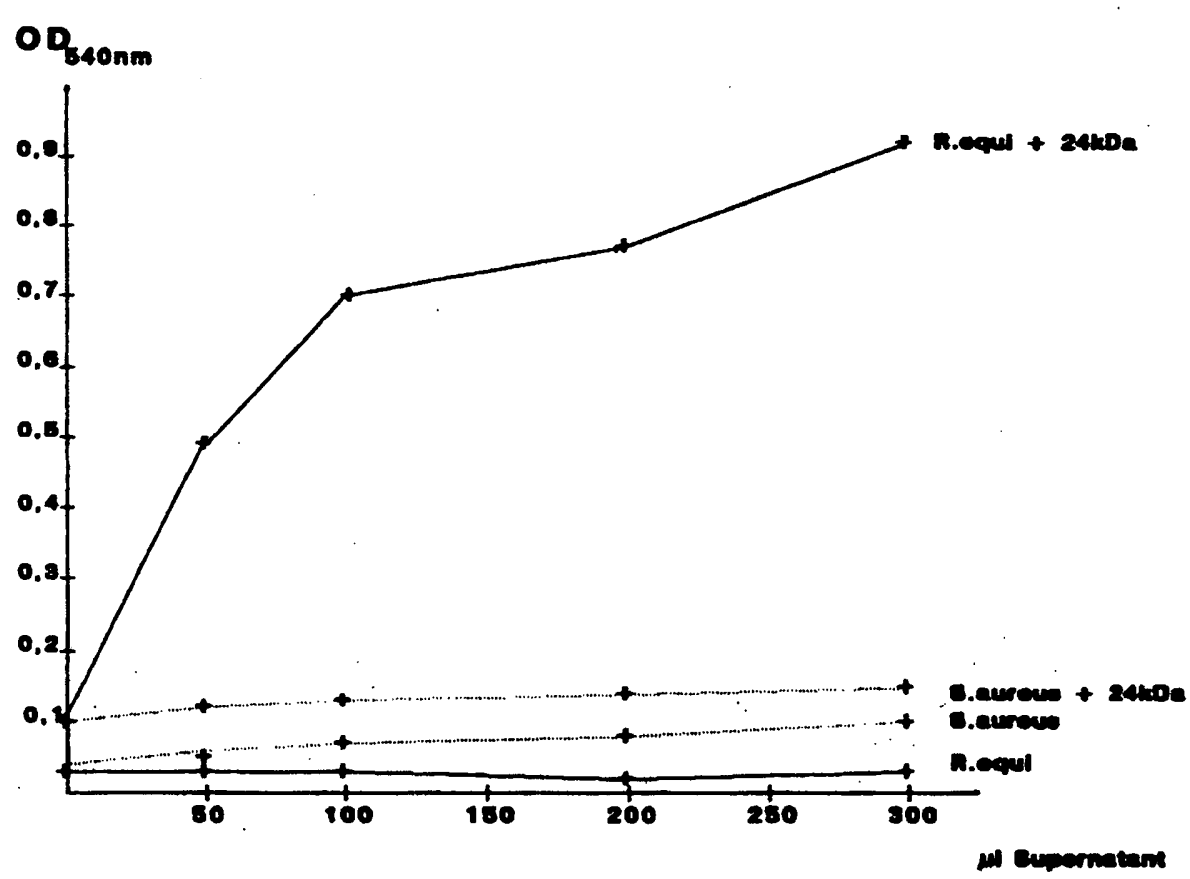

Figure 2: CAMP-effect of the purified $24 \mathrm{kDa}$ protein from Listeria ivanovii (measured by the release of hemoglobin from sheep erythrocytes). The values were determined after combining the indicated amounts of 10 fold concentrated culture supernatants from S. aureus or Rhodococcus equi with a constant amount of the purified 24 $\mathrm{kDa}$ protein from Listeria ivanovii. the listeriolysin preparation from $L$. ivanovii was tested by immunoblotting techniques (12) against supernatant proteins from several Listeria strains. Figure 4 shows that these antibodies react specifically with two proteins of $\mathrm{Mr}$ $58 \mathrm{kDa}$ and $24 \mathrm{kDa}$, respectively, from $L$. ivanovii (as expected) and with one major protein from the other Listeria strains tested. These data agree with similar experiments using anti-SLO to detect listeriolysin in the supernatants of Listeria strains. The major conclusions from these data are: (a) All tested virulent strains of $L$. monocytogenes produce a protein of MW 58 to $60 \mathrm{kDa}$ which cross reacts with anti-SLO and is presumed, on the basis of its biochemical characteristics, to represent listeriolysin. This protein is therefore most likely listeriolysin. The amount of this protein is, however, significantly different in the various $L$. monocytogenes strains; (b) No protein cross-reacting with anti-SLO was present in the supernatant from several strains of $L$. innocua (Sv6a and Sv6b), Listeria welshimeri, Listeria grayi and Listeria murrayi. The avirulent but hemolytic $L$. seeligeri strains did not cross react with these antibodies (Figure 4B), a finding which indicates that the hemolysin produced by $L$. seeli- geri is different from the listeriolysin of $L$. monocytogenes.

\section{Characterization of Hemolytic Clones from a Gene Library of Listeria monocytogenes}

A gene library of $L$. monocytogenes $1 / 2$ a strain EGD was constructed using the vector pUC18. The EGD strain was obtained from S. H. E. Kaufmann (MPI of Immunobiology, Freiburg), who originally obtained it from $G$. $B$. Mackaness (Saranac Lake, N.Y.). The strain is weakly hemolytic and has a $\mathrm{LD}_{50}$ of about $10^{4}$ organisms for BALB/c and NMRI mice.

Ten thousand recombinants with inserts of 1 to $15 \mathrm{~kb}$ of Listeria DNA were screened on blood agar plates for hemolytic phenotype. A recombinant was identified that showed hemolytic activity on such agar plates after three to four days of growth. The hemolytic activity was cell-associated and could not be detected in supernatant fluids. The recombinant plasmid, designated pLM1, was found to contain an insert of $3.4 \mathrm{~kb}$ Listeria DNA. Using deletion mutants created by restriction endonucleases we
1

A. Asp Ala Ser Val Tyr Ser Tyr Gln Gly Ile Ile

(Pro)Ala $X$ Pro(Pro)Ala Lys ...

B. Ala Asp Ile Leu $x$ Pro Met Pro Ile Asn Gln Ile Phe Pro Asp

Pro Asp Leu Ala...

(Leu)
10

10

$X$ His Met Ala

(Pro) Figure 3: Amino acid sequence analysis of the $\mathrm{N}$-terminal end of the purified $58 \mathrm{kDa}$ and the $24 \mathrm{kDa}$ proteins from Listeria ivanovii. $(X)$ refers to amino acid positions which most likely represent Cys. Amino acids in parenthesis are possible alternatives to the amino acids shown above or their presence is uncertain. 


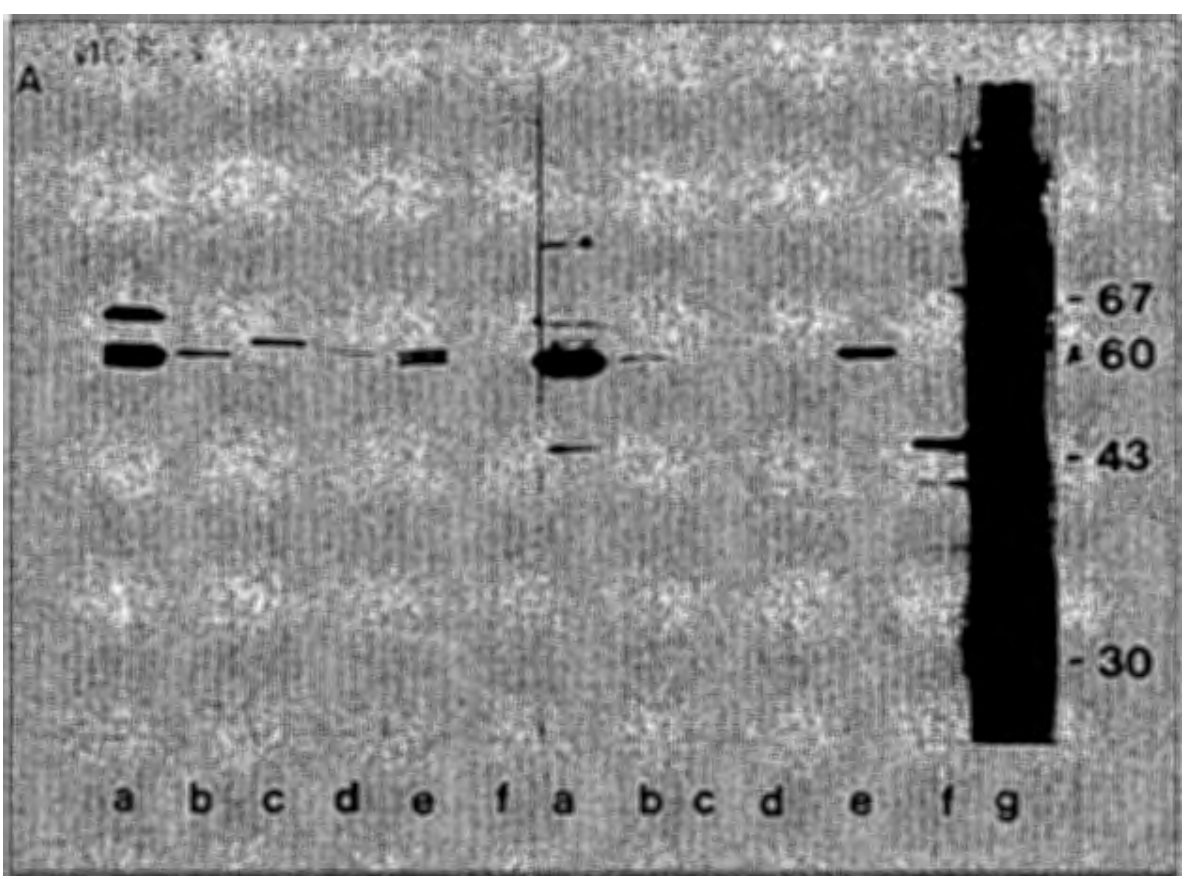

Figure 4: Western blot analysis of extracellular proteins from virulent and avirulent Listeria strains with anti-listeriolysin and anti-SLO antibodies. Left panel: reaction with anti-listeriolysin; right panel: reaction with antiSLO. The cross reaction of proteins with a $\mathrm{Mr}$ of around $60 \mathrm{kDa}$ with antilisteriolysin antiserum in the lanes showing extracellular proteins from Listeria monocytogenes Sv1/2a EGD (c), Listeria innocua (d) and Listeria monocytogenes Sv1/2a, Mackaness (e) is most probably caused by a contamination of the anti-listeriolysin antiserum with anti $60 \mathrm{kDa}$ antibodies (see Figure 11). Listeria monocytogenes Sv1/2a. EGD produces very little listeriolysin which cannot be seen as cross hybridizing band in this figure. Part A: (a) Listeria ivanovii; (b) Listeria monocytogenes Sv4b; (c) Listeria

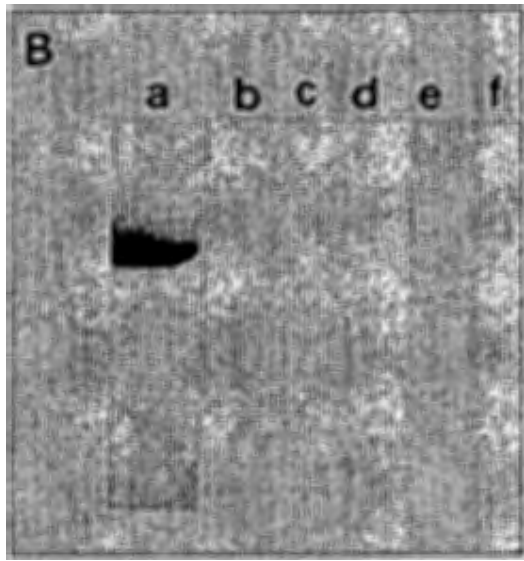

monocytogenes Sv1/2a (EGD); (d) Listeria innocua; (e) Listeria monocytogenes Sv1/2a; (f) $S$. pyogenes; g: molecular weight markers. Part B: Lack of cross-reactivity of extracellular proteins from Listeria seeligeri with antiSLO. SDS-PAGE and immunoblotting were performed as described (12). Lanes: (a) Listeria monocytogenes (strain SLCC 5764); (b-f) Listeria seeligeri (SLCC strains 3644, 4113, 4061, 3776, and 5921, respectively). were able to locate the DNA to approximately $2 \mathrm{~kb}$ of Listeria DNA. A $23 \mathrm{kDa}$ protein is unique to all recombinants producing the hemolysin. The hemolytic factor encoded by plasmid pLM1 is neither activated by reducing agents nor does it cross react with anti-SLO or antilisteriolysin antisera. We therefore conclude that the recombinant codes for a hemolytic principle are distinct from listeriolysin.

In a further attempt to identify recombinants harbouring the gene for listeriolysin we screened the gene library for clones exhibiting cross reactivity to anti-SLO. Using this approach we identified seven recombinant strains that specifically cross react with anti-SLO. Of these, two re- combinants also showed cross reactivity to anti-listeriolysin (see above). DNA hybridization with these plasmids showed that they carried common sequences. One recombinant, designated pLM37, is described in more detail. The strain harbouring the plasmid pLM37 was found to produce small zones of hemolysis after overnight growth on human blood agar plates. Spontaneous lysis of overnight cultures was often observed and may explain our inability to detect the recombinant in the initial screen for hemolytic recombinants.

The plasmid has an insert of $9 \mathrm{~kb}$ of Listeria DNA. A partial restriction endonuclease map was constructed and is depicted in Figure 5. Polypeptides of $61 \mathrm{KDa}, 42 \mathrm{KDa}$

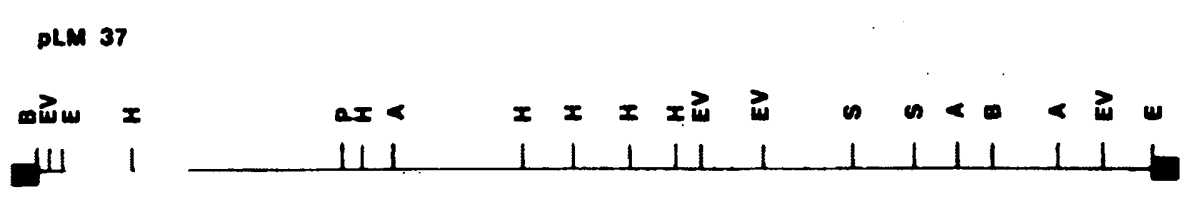

a.4kb

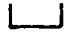

Figure 5: Restriction endonuclease map of pLM37. The closed boxes represent vector pUC18 DNA sequence. The region underlined is required for the expression and production of a hemolysin which may represent listeriolysin. Abbreviations: $A=$ AvaI; $B=$ BamHI; $E=E \operatorname{coRI} ; E V=E \operatorname{CoRV} ; H=$ HindIII; $P=\underline{\text { PstI }} ; S=\underline{\text { SmaI. }}$ 


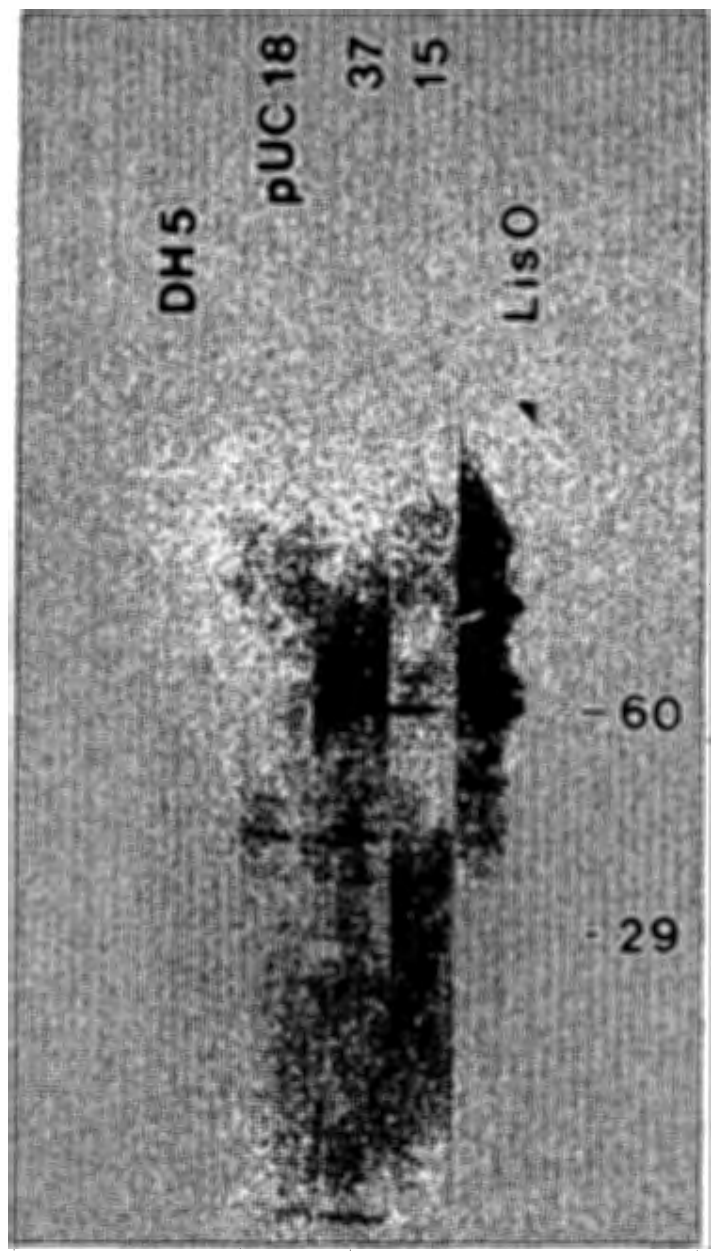

Figure 6: Immunoblots of whole cell lysates from Escherichia coli DH5 strains with rabbit antisera to listeriolysin. Specific reactivity to a $60 \mathrm{kDa}$ protein is seen in recombinants harbouring plasmids PLM15 and pLM37 which is not present in the recipient strain $\mathrm{DH} 5$ with and without vector pUC18. Lane marked Lis $O$ contains a partially purified fraction of listeriolysin from Listeria ivanovii.

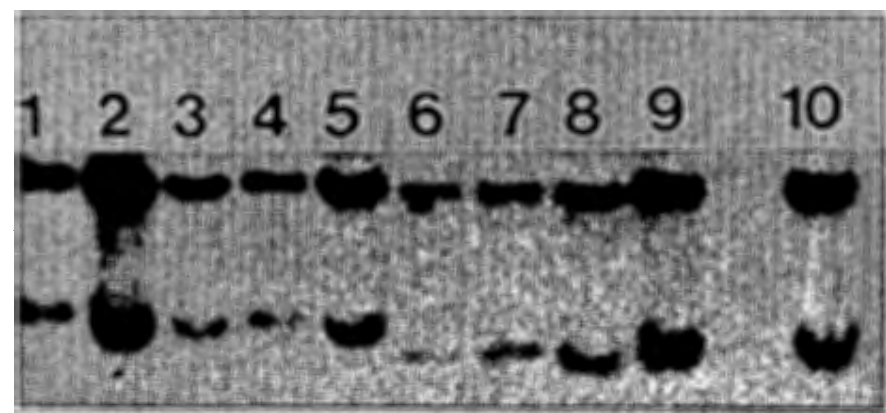

Figure 7: Southern Blot hybridization of HindIII-cleaved chromosomal DNA from type I (1-5) and type II (6-10) hemolysin-negative. Tn916 insertion mutants from Listeria monocytogenes (Sv1/2a) with ${ }^{32}$ P-labelled Tn916 DNA (cloned in pBR 322). The sizes of the upper HindIII fragments are around $12 \mathrm{~kb}$ and $11 \mathrm{~kb}$, respectively, the sizes of the lower HindIII fragments $6.5 \mathrm{~kb}$ and $5.5 \mathrm{~kb}$, respectively. and $30.5 \mathrm{kDa}$ are encoded by the DNA insert of pLM37. In immunoblot assays using both anti-SLO and anti-listeriolysin antisera, the $61 \mathrm{kDa}$ protein was found to be the cross reacting polypeptide (Figure 6). While the recombinant showed detectable levels of hemolytic activity in liquid assays, we have not yet been able to demonstrate convincingly enhancement of this activity using DTT or cystein.

Preliminary data using a probe obtained from the plasmid pLM37 showed that the cloned fragment is present only in L. monocytogenes strains. Hybridization with the plasmid pLM1, in contrast, showed that this DNA sequence is present in all Listeria species tested except $L$. murrayi and $L$. grayi.

\section{Isolation of Nonhemolytic (Hly) Mutants of Listeria mo- nocytogenes by Transposon Mutagenesis}

Several Hly mutants of $L$. monocytogenes were isolated by $\operatorname{Tn} 916$ mutagenesis as described (5). These mutants have been characterized with respect to the proteins they produce extracellularly. Two types were identified, one (type I) producing no anti SLO-reacting protein of 58 $\mathrm{kDa}$, and another (type II) producing smaller polypeptides, of which one, of $\mathrm{MW} 49 \mathrm{kDa}$, reacted noticeably with anti SLO antiserum and probably represented a truncated form of the listeriolysin. The absence of the 58 $\mathrm{kDa}$ protein in the type I mutants and the production of the $49 \mathrm{kDa}$ polypeptide in the type II mutants were also observed in total cellular proteins (data not shown), suggesting that the nonhemolytic phenotype was not due to lack of transport of the protein extracellularly, but that, instead, intact, active hemolysin was not produced by these mutants.

Hybridization of HindIII-digested chromosomal DNA from Hly mutants with ${ }^{32} \mathrm{P}$-labeled Tn916 indicated the presence of two hybridizing HindIII fragments, suggesting that single copies of Tn916 were inserted in the DNA of these mutants ( $\mathrm{Tn} 916$ has a single HindIII site). Type II mutants were probably due to insertions of Tn916 within the structural gene for the hemolysin, since they produced a truncated, inactive, protein. Type I mutants may well be due to insertions of $\mathrm{Tn} 916$ in a regulatory sequence, the proximity of which to the structural gene is currently being studied. The sum of the two hybridizing HindIII fragments was the same for all mutants of a given type (Figure 7). Tn916 is localized in different HindIII fragments in the two types of mutants, as indicated by the fact that the sum of the two hybridizing HindIII fragments of type I mutants is different from that of type II (Figure 7). We are currently involved in the cloning of the DNA sequences immediately adjacent to the point of insertion of Tn916 in the two types of mutants.

\section{Hemolysin as Virulence Factor}

Both types of hemolysin-negative Tn916 insertion mutants showed significantly reduced virulence in the mouse 


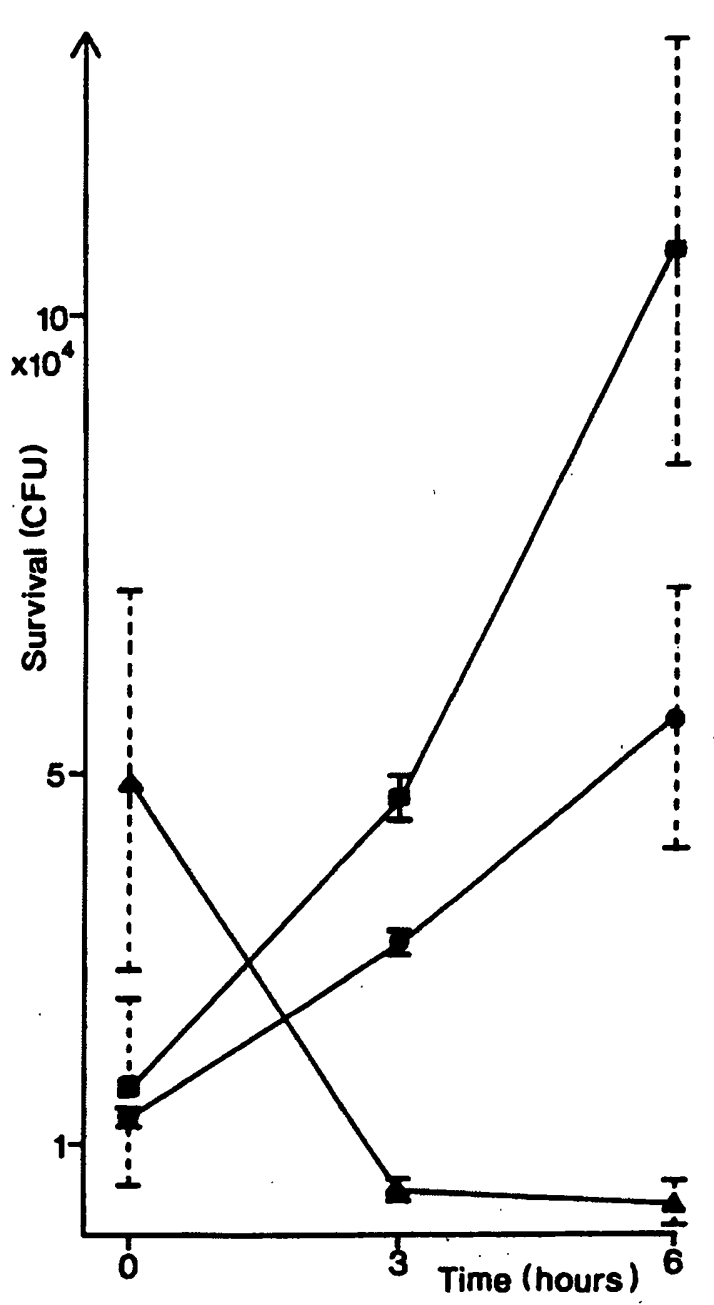

Figure 8: Survival of Listeria monocytogenes Sv1/2a wildtype strain and Hly ${ }^{-}$mutant within mouse peritoneal macrophages. Peritoneal macrophages from three-months-old $\mathrm{BALB} / \mathrm{C}$ mice were harvested and washed in PBS and resuspended in RPMI 1640 medium (Seromed) supplemented with $10 \%$ fetal calf serum and L-glutamine. $5 \times 10^{5}$ macrophages were infected with $5 \times 10^{6}$ bacteria. After 40 min of phagocytosis, the cultures were washed five times with $5 \mathrm{ml}$ PBS to remove excess extracellular bacteria and reincubated for $40 \mathrm{~min}$ in medium containing $50 \mu \mathrm{g} / \mathrm{ml}$ gentamicin to kill residual or adherent bacteria not removed by the washing steps. After removal of the drug, the medium was changed every hour for the duration of the experiment $(3-6$ h). Each point in the figure represents an average of two experimental values. The deviations of the two values are indicated by the dashed lines. These experiments were repeated several times with different batches of peritoneal mouse macrophages and yielded qualitatively the same results.

- Listeria monocytogenes (Sv 1/2a) wild-type strains $\mathrm{Hly}^{+}$; - Listeria monocytogenes $\mathrm{Tc}^{\mathrm{R}}$ (due to a Tn916 insertion, $\mathrm{Hly}^{+}$;

$\Delta$ Listeria monocytogenes $\mathrm{Tc}^{\mathrm{R}} \mathrm{Hly}^{-}$(due to a Tn916 insertion in the structural hly gene).

model system as previously reported (5). Similar results have been obtained with a Tn1545 induced hemolysinnegative mutant (4).

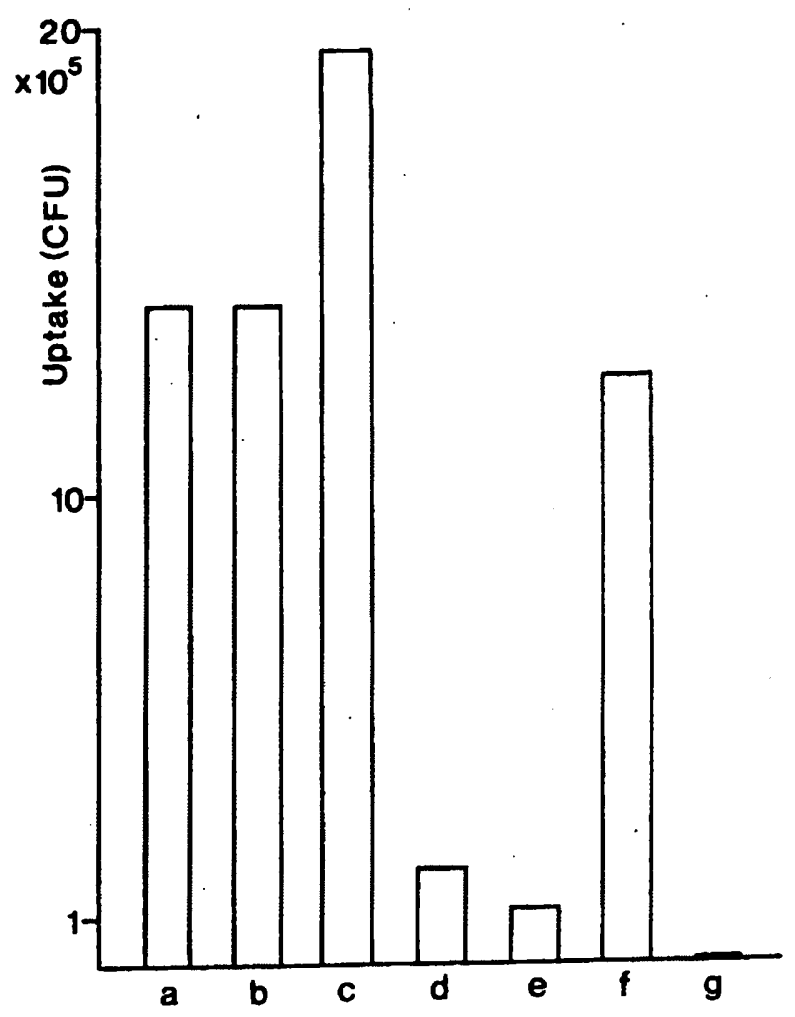

Figure 9: Uptake of $\mathrm{Hly}^{+}$and Hly- strains of Listeria monocytogenes by 3 T6 fibroblast cells. Uptake assays were performed essentially as described (13). 106 3 T6 cells per well were infected with $10^{7}$ bacteria. Each column represents the mean value of two experiments (a) Listeria monocytogenes (Sv 1/2a - Mackaness); (b) Listeria monocytogenes (Sv 1/2a-strain EGD); (c) Listeria monocytogenes (Sv4b); (d) Listeria monocytogenes (Sv3a); (e) Listeria innocua (Sv6a); (f) Listeria monocytogenes (Sv 1/2a-Mackaness) Tcr, Hly(Tn916 mutant); (g) - Bacillus subtilis.

To examine the possible role of hemolysin in the uptake and/or survival of $L$. monocytogenes we have been studying the interactions between the $\mathrm{Hly}^{+}$and $\mathrm{Hly}^{-}$L. monocytogenes strains and professional (peritoneal mouse macrophages) and nonprofessional phagocytic cells (3T6 mouse embryo fibroblast cell line). Unopsonized Listeria cells were mixed with macrophages in a ratio of ten bacteria per macrophage. Bacteria that remained outside the macrophages were killed by gentamicin as described (13) and the number of viable bacteria within the macrophages was determined at time 0 and $3 \mathrm{~h}$ and $6 \mathrm{~h}$ thereafter. The $\mathrm{Hly}^{+}$bacteria were able to multiply and after $6 \mathrm{~h}$ a 10 -fold increase in their number was observed. In contrast to this, the $\mathrm{Hly}^{-}$bacteria failed to multiply inside the macrophages and their numbers declined steadily, so that at $6 \mathrm{~h}$ only $10 \%$ of the bacteria present at time 0 remained (Figure 8). These data suggest that the ability of the bacteria to survive and multiply within the macrophages is severely impaired in the $\mathrm{Hly}^{-}$mutants. $\mathrm{Hly}^{+}$and $\mathrm{Hly}^{-} L$. monocytogenes are identical in terms of their ability to be internalized by non professional phagocytes (Figure 9). 
(Gly) (Gly)

\section{0}

Gln Ser Lys Gly Thr (Thr) Val Thr ...
Figure 10: N-terminal amino acid sequence of the purified $60 \mathrm{kDa}$ protein from Listeria monocytogenes. The $60 \mathrm{kDa}$ protein was isolated from a Hly- transposon mutant and further purified by SDS-PAGE. The protein band was eluted directly from the gel. Amino acids in parenthesis are possible alternatives to the amino acids shown in the sequence above or their presence is uncertain.
Following centrifugation with 3T6 cell monolayers $\mathrm{Hly}^{+}$ and $\mathrm{Hly}^{-}$bacteria were able to be internalized by the cells with similar frequencies. Internalization is probably due to phagocytosis, since it was strongly inhibited by cytochalasin B, an inhibitor of microfilament function. In contrast to the Hly ${ }^{-}$mutants of $L$. monocytogenes two other Listeria strains, the avirulent nonhemolytic $L$. innocua (Sv6a) and the slightly virulent, hemolytic $L$. monocyto genes (Sv3a) do not enter these host cells to any appreciable extent, similar to $B$. subtilis which was used as a noninvasive control bacterium. These data show convincingly that fully virulent Listeria must possess an active mechanism for invasion of mammalian cells. Listeriolysin is clearly not involved in this invasion step.

All virulent strains of $L$. monocytogenes capable of penetrating nonprofessional phagocytic cells, synthesize and secrete in relatively high concentration a protein of 60 $\mathrm{kDa}$. It can be clearly distinguished from listeriolysin by several criteria:

(a) It is still present in both classes of $\mathrm{Hly}^{-}$mutants ob- tained by Tn916 insertion;

(b) It is well separated from listeriolysin on $2 \mathrm{D}$-gels by its alkaline isoelectric point ( $\mathrm{pH} 8.5$; listeriolysin $\mathrm{pH} 7.0$ );

(c) The $\mathrm{N}$-terminal amino acid sequence of the purified $60 \mathrm{kDa}$ protein (Figure 10 ) is totally different from the Nterminal sequence of listeriolysin from $L$. ivanovii;

(d) Antibodies raised against the $60 \mathrm{kDa}$ protein do not cross-react with listeriolysin (Figure 11).

Figure 11 also shows that a protein of this size is either absent or significantly reduced in its amount in the tested avirulent strains. Most of the latter strains secrete, however, proteins of different sizes which cross-react with the antiserum against the $60 \mathrm{kDa}$ protein.

Mutants were isolated from two virulent $L$. monocytogenes strains (Sv1/2a) which produced significantly lower levels of the $60 \mathrm{kDa}$ protein than the corresponding wildtype strains (Figure 12A). These mutants also showed a reduced ability to penetrate $3 \mathrm{~T} 6$ cells (Figure 12B). These lines of evidence suggest that the $60 \mathrm{kDa}$ protein may play a role in the invasion process.

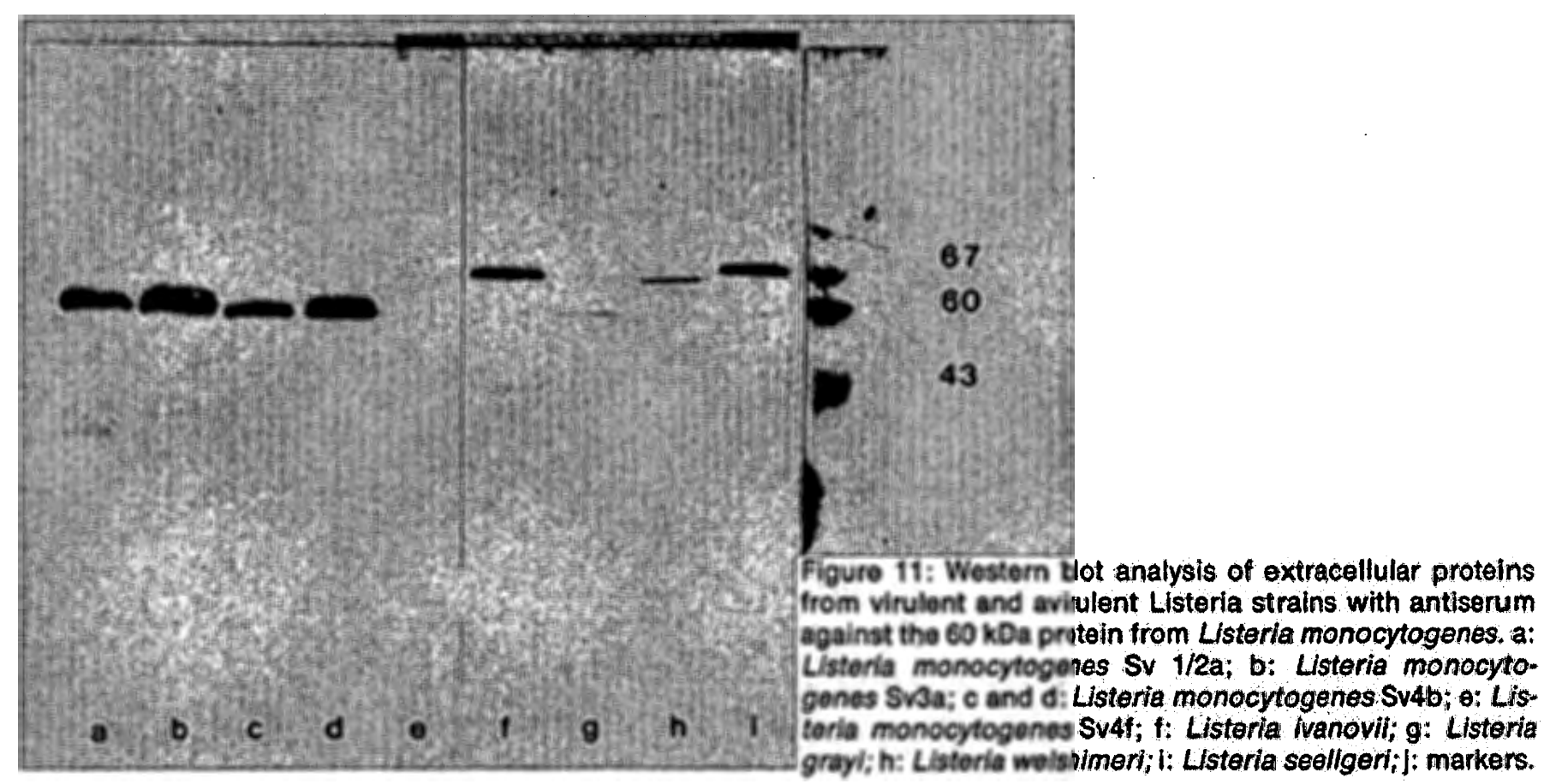




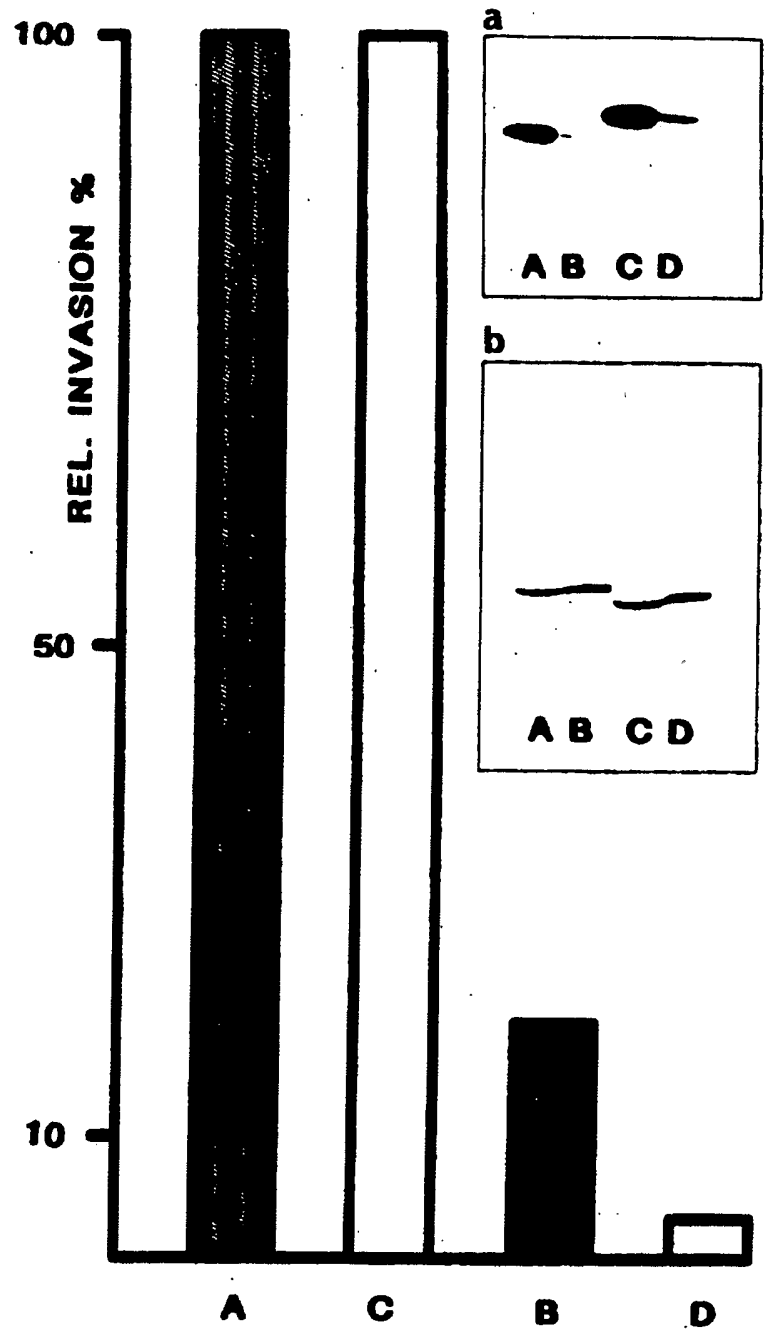

Figure 12: Correlation between reduced synthesis of the 60 $\mathrm{kDa}$ protein and reduced ability of mutants from Listeria monocytogenes $1 / 2 a$ to enter 3T6 cells. $a, b$ : Western blot analysis of extracellular proteins from wild-type $(A, C)$ and mutants (B, D) of two Listeria monocytogenes Sv1/2a strains. (a): gel developed with antiserum against the 60 kDa protein; (b): gel developed with anti-SLO. Diagram shows the ability of the same wild-type and mutant strains as above to enter $3 T 6$ cells. Experimental conditions were the same as described in Figure 9.

\section{Acknowledgements}

This work was supported by a grant from the Deutsche Forschungsgemeinschaft (SFB 165 B4). We thank Dr. Lotspeich (München) for carrying out the amino acid sequence analysis and E. Appel for editorial assistance.
Literature

1. Rocourt, J., Alonso, J. M., Seeliger, H. P. R.: Virulence comparée des cinq groupes génomiques de Listeria monocytogenes (sensu lato). Ann. Microbiol. (Paris) 134A (1983) 359-364.

2. Hof, H.:Virulence of different strains of Listeria monocytogenes serovar 1/2a. Med. Microb. Immun. 137 (1984) 207-218.

3. Seeliger, H. P. R., Schrettenbrunner, A., Pongratz, G., Hof, H.:Zur Sonderstellung stark hämolysierender Stämme der Gattung Listeria. Zbl. Hyg., I. Abt. Orig. A. 252 (1982) 176-190.

4. Gaillard, J. L., Berche, P., Sansonetti, P.: Transposon mutagenesis as a tool to study the role of hemolysin in the virulence of Listeria monocytogenes. Infect. Immun. 52 (1986) 50-55.

5. Kathariou, S., Metz, P., Hof, H., Goebel, W.: Tn916-induced mutations in the hemolysin determinant affecting virulence of Listeria monocytogenes. J. Bacteriol. 169 (1987) 1291-1297.

6. Parrisius, J., Bhakdi, S., Roth, M., Tranum-Jensen, J., Goebel, W., Seeliger, H. P. R.: Production of listeriolysin by beta-hemolytic strains of Listeria monocytogenes. Infect. Immun. 51 (1986) 314-319.

7. Smyth, C. J., Duncan, J. L.: Thiol-activated (oxygen-labile) cytolysins. In: Jeljaszewicz, J., Wadstrom, T., (eds): Bacterial toxins and cell membranes, Academic Press, New York 1987, pp. 129-183.

8. Njoku-Obi, A. N., Jenkins, E. M., Njoku-Obi, J. C., Adams, J., Covington, V.: Production and nature of Listeria monocytogenes hemolysin. J. Bacteriol. 86 (1963) 1-8.

9. Geoffroy, C., Alouf, J. E.: Selective purification by thiol-disulfide interchange chromatography of alveolysin, a sulfhydryl-activated toxin of Bacillus alvei. J. Biol. Chem. 258 (1983) 9968-9972.

10. Fraser, G.: A plate method for the rapid identification of Listeria (Erysipelothrix) monocytogenes. Vet. Res. 74 (1962) 50-51.

11. Alouf, J. E., Geoffroy, C., Gilles, A.-M., Falmagne, P.: Structural relatedness between five bacterial sulfhydryl activated toxins: Streptolysin O, Perfringolysin O, Alveolysin, Pneumolysin and Thuringiolysin. In: Alouf, J. E., Fehrenbach, F. J., Jeljaszewiczy, J., Thelestam, $M$. (eds): Bacterial protein toxins. G. Fischer 1986, pp. 49-50.

12. Towbin, H., Staehelin T., Gordon, J.: Electrophoretic transfer of proteins from polyacrylamide gels to nitrocellulose filters: procedure and some applications. Proc. Natl. Acad. Sci. USA 76 (1979) $4350-4353$.

13. Isberg, R. R., Falkow, S.: A single genetic-locus encoded by Yersinia pseudotuberculosis permits invasion of cultured animal cells by Escherichia coli K-12. Nature 317 (1985) 262-264. 